\title{
Pengembangan Modul Belajar Bahasa Mandarin di BLK PT Trias Insan Madan
}

\author{
Rizky Fahrenza, ${ }^{\square}$ Cecep Kustandi $^{2}$, Kunto Imbar Prasetyo ${ }^{3}$ \\ ${ }^{1}$ Universitas Negeri Jakarta, Jakarta, Indonesia. \\ ${ }^{2}$ Universitas Negeri Jakarta, Jakarta, Indonesia. \\ 3 Universitas Negeri Jakarta, Jakarta, Indonesia. \\ DOI: https://doi.org/10.21009/JPI.o31.10
}

\begin{abstract}
Article History Abstrak
Received : 2020

Accepted : 2020

Published : 2020

Penelitian pengembangan ini menghasilkan sebuah media cetak berupa Modul Belajar Dasar-Dasar Bahasa Mandarin. Secara umum penelitian pengembangan ini mempunyai tujuan menghasilkan modul cetak untuk memfasilitasi peserta pelatihan berlatih berbicara bahasa Mandarin dalam pekerjaan mereka sehari-hari.

\section{Keywords}

Module Development; Rowntree Model; Mandarin; Pengembangan modul ini mengacu pada model pengembangan produk yaitu Model Rowntree. Model ini membagi tahapan pengembangan dalam tiga tahapan, tahap perencanaan, tahapan persiapan penulisan, dan tahap penulisan dan penyuntingan. Penelitian ini menggunakan evaluasi formatif dengan melibatkan 2 ahli materi, 1 ahli media, dan 1 ahli desain pembelajaran. Hasil ujicoba yang didapat secara keseluruhan baik dengan nilai rata-rata 5,72 dari 7. Data dari one-to-one mendapatkan nilai rata-rata 6,44 dari 7. Sedangkan data dari small group mendapatkan nilai rata-rata 6,45 dari 7, artinya modul dapat dinilai sangat baik. Berdasarkan proses dan prosedur dalam mengembangkan modul, serta ujicoba yang telah dilakukan dapat dinyatakan bahwa modul belajar dasardasar bahasa Mandarin memiliki kualitas yang baik dan layak untuk digunakan sebagai sumber belajar.
\end{abstract}

\begin{abstract}
The development research aims to produce products such as "print instructional materials" basic fundamental of mandarin module. This module can be used as a learning resource. In general, this development research is aimed to result a module to facilitate learner practice speaking Mandarin about their job. Developers use the model product development presented by Rowntree. This model have 3 steps, planning, preparation of writing, writing and editing. Evaluation on this development it using formative evaluation involving three experts that 2 matter experts, 1 media experts, and 1 instructional design experts. The results, from the data of their test is very well with the average value of 5,72 of the scale 7 The data obtained from the oneto-one result get the average value of 6.44 of the scale 7 and the average value of small group is 6,45 of 7. Which means this module is very appropriate. . Based on process and procedures in developing module, as well as the trial that has been carried out can be expressed that the module has good quality and can be used to facilitate learner of working centre Trias Insan Madani company and this module can be used as a learning resource.
\end{abstract}

\footnotetext{
$\triangle$ Corresponding author : Rizky Fahrenza Adress: Universitas Negeri Jakarta

Jakata, Indonesia

E-mail: rfahrenza@yahoo.co.id
}

(C) 2020 Universitas Negeri Jakarta 


\section{PENDAHULUAN}

Pendidikan menurut Edgar Dale yang dikutip oleh Eko Yulianto adalah suatu usaha yang dilakukan dengan sadar oleh keluarga, masyarakat, atau pemerintah melalui bimbingan, pengajaran, pembelajaran dan pelatihan yang berlangsung, baik di sekolah maupun diluar sekolah sepanjang hidup untuk mempersiapkan peserta didik agar dapat menjalankan perannya dalam lingkungan untuk masa yang akan datang.

Perkembangan zaman, khususnya pada zaman moderen ini, pendidikan menjadi sebuah keharusan. Pendidikan merupakan bekal sekaligus investasi bagi semua manusia di masa depan. Perkembangan zaman yang cepat membuat manusa berlomba-lomba untuk mencari pekerjaan baik di dalam negeri maupun di luar negeri. Untuk mendapatkan pekerjaan manusia harus mempunyai pengetahuan serta skill yang memadai melalui pendidikan dan pelatihan.

Instruksi Presiden No. 15 tahun 1974 dalam H. Mustofa, pelatihan diartikan sebagai bagian pendidikan yang menyangkut proses belajar untuk memperoleh dan meningkatkan keterampilan di luar sistem pendidikan yang berlaku, dalam waktu yang relatif singkat, dan dengan menggunakan metode yang lebih mengutamakan praktik daripada teori. Pelatihan juga merupakan satu intervensi yang sering dilakukan oleh lembaga atau organisasi untuk dapat meningkatkan kinerja sumber daya alam yang ada di dalamnya.

PT. Trias merupakan perusahaan yang bergerak di bidang jasa, berdiri tahun 2009 . Perusahaan ini memberikan layanan jasa berupa caretaker, housekeeper yang akan dipersiapkan dan dlatih sebelumnya untuk bekerja di luar negeri. Perusahaan ini memiliki Balai Latihan Kerja (BLK) sendiri yang akan membimbing karyawannya untuk siap dipekerjakan ke luar negeri, seperti Taiwan, Hongkong, Singapura.

Kegiatan pelatihan yang diadakan tersebut tentunya memerlukan sumber belajar yang dapat memfasilitasi belajar para peserta pelatihan. Salah satu sumber belajar yang digunakan adalah modul. Terdapat dua jenis modul yang ada di pelatihan tersebut, antara lain modul Bahasa Mandarin dan modul penjurusan.

Berdasarkan observasi dan wawancara dengan beberapa peserta pelatihan. Mereka memiliki masalah yang dihadapi, yaitu kesulitan untuk menyusun kalimat dalam Bahasa Mandarin. Selain itu, bentuk fisik modul belum terstruktur dengan baik, kurang komunikatif, kurangnya visual pendukung, dan belum adanya tes formatif pada setiap materi yang disajikan.

Karena peraturan yang mengharuskan peserta pelatihan tidak boleh menggunakan gadget pada hari belajar (senin-jumat). Berdasarkan masalah diatas, pengembang tertarik untuk mengembangkan modul untuk belajar berbahasa mandarin. Modul tersebut mencakup materi - materi dasar-dasar tentang cara memperkenalkan diri, menyapa, mengangkat telepon, berbelanja, mengetahui kosakata makanan dan alat dapur, sertakosakata dalam rumah tangga menggunakan bahasa mandarin.

\section{METODE}

Penelitian ini menggunakan model pengembangan yang berorientasi pada produk, yaitu model Rowntree. Model ini terkonsentrasi pada produksi bahan ajar tertentu sehingga kejelasan pelaksanaan kegiatan desain pembelajaran mudah diikuti setiap langkahnya. Menurut Rowntree, ada tiga langkah yang harus dilakukan untuk memproduksi, diantaranya: tahap perencanaan, tahap persiapan penulisan, serta tahap penulisan dan penyuntingan. ${ }^{1}$

\section{Tahap Perencanaan}

1. Mengetahui profil peserta pelatihan, Mengenal peserta didik adalah hal yang penting untuk dilakukan. Hal pertama yang dilakukan oleh pengembang adalah menganalisis peserta didik dengan cara melakukan wawancara kepada kepala balai latihan kerja dan instruktur. Melalui wawancara tersebut, pengembang memperoleh profil peserta didik yang akan menggunakan modul ini. 
2. Merumuskan tujuan umum dan khusus,

Setelah melakukan analisis peserta didik, pengembang merumuskan tujuan pembelajaran dengan cara berdiskusi dengan ahli materi, mengkaji RPP yang sudah ada sebelumnya, dan menyesuaikan dengan kompetensi - kompetensi yang dibutuhkan untuk mencapai tujuan pembelajaran.

3. Menyusun Garis Besar Isi,

Setelah menentukan tujuan pembelajaran, tahap selanjutnya adalah menyusun garis besar isi pembelajaran. Tahapan ini pengembang mengacu pada silabus balai latihan kerja yang dimiliki oleh PT. Trias Insan Madani, berdiskusi dengan instruktur di tempat tersebut, membaca modul yang telah ada sebelumnya, serta membaca literatur yang relevan.

4. Menentukan Media,

Dalam memilih media pembelajaran yang akan digunakan, pengembang melakukan sebuah wawancara dengan kepala balai latihan kerja dan instruktur serta mengikuti pelatihan untuk melakukan observasi. Hal tersebut dilakukan untuk mengetahui, media apa yang cocok untuk digunakan oleh peserta pelatihan.

5. Merencanakan pendukung belajar,

Tahapan ini, menurut model Rowntree pendukung belajar yang dimaksudkan adalah sumber belajar manusia yang dapat membantu peserta pelatihan mencapai tujuan. Oleh karena itu, pengembang merencanakan instruktur dan kepala balai latihan kerja sebagai sumber belajar sekaligus fasilitator. Selain itu, pengembang juga merencakan teman dan alumni sebagai sumber belajar sekaligus untuk berbagi pengalaman bagi peserta pelatihan.

6. Mempertimbangkan bahan ajar yang sudah ada.

Khususnya pada modul yang sudah ada sebelumnya, pengembang merasa masih banyak kekurangannya karena bentuknya seperti kurang menarik karena tidak adanya grafis, dan belum adanya evaluasi pada modul tersebut. Dalam hal ini, pengembang melihat kelebihan dan kekurangannya sebagai acuan dalam pengembangan modul.

\section{Tahap Persiapan Penulisan}

1. Mempertimbangkan sumber daya dan hambatannya

Tahapan ini, pengembang mempertimbangkan hambatan-hambatan dalam prnyusunan modul agar modul ini dapat terselesaikan dengan baik. Adapun beberapa hambatan yang diperkirakan oleh pengembang, antara lain:

- Keterbatasan waktu dalam mengembangkan modul

- Biaya produksi yang mahal

- Keterbatasan pengembang mengetik ejaan atau kalimat dalam bahasa mandarin

2. Mengurutkan ide atau gagasan

Tahapan ini, pengembang berkonsultasi dengan ahli materi yaitu Louse Nur Trias sebagai kepala balai latihan kerja sekaligus instruktur pelatihan. Dalam hal tersebut, pengembang mengurutkan susunan materi yang akan dipelajari terlebih dahulu dalam modul yang akan dikembangkan.

3. Mengembangkan aktivitas dan umpan balik Tahapan ini, pengembang berdiskusi dengan ahli materi untuk memberikan aktivitas dan umpan balik, yakni dengan memberikan tes formatif.

4. Menentukan contoh-contoh terkait

Materi akan lebih jelas apabila dibeikan contoh untuk menambah pemahaman. Tahapan ini, pengembang berdiskusi dengan ahli materi untuk memberikan contoh yang berkaitan pada tiap kegiatan pembelajaran. Contoh-contoh yang diberikan biasanya berkaitan dengan kehidupan sehari-hari atau pengalaman pribadi.

5. Menentukan Grafis

Tahapan ini, pengembang menganalisis dan berdiskusi dengan ahli materi tentang materi apa saja yang membutuhkan grafis untuk meningkatkan pemahaman peserta pelatihan. 
6. Menentukan Peralatan yang dibutuhkan Tahapan ini, pengembang membuat learning guidance dan latihan pada setiap kegiatan pembelajaran. Selain itu akan dibuatkan juga daftar isi serta glosarium untuk mempermudah peserta pelatihan menggunakan modul ini.

7. Menentukan Format Fisik

Tahapan ini, pengembang menentukan format fisik modul yang akan dikembangkan. Penentuan ini juga di diskusikan kepada pihak balai latihan kerja untuk mengikuti format yang akan disesuaikan oleh pihak lembaga.

\section{Tahap Penulisan dan Penyuntingan}

1. Menulis draft

Setelah selesai melakukan dua tahap sebelumnya, selanjutnya ialah tahapan terakhir. Dimulai dari menulis draft yang sesuai dari garis besar isi modul. Agar lebih mudah dalam melakukan pengembangannya, draft modul dibuat perkegiatan pembelajaran atau sub materi. Nantinya setiap kegiatan pembelajaran mempunyai draft nya masing-masing

2. Melengkapi dan menyunting draft awal

Setelah semua draft tersusun dan digabungkan dengan susunan materi yang telah dibuat sebelumnya. Lalu, langkah selanjutnya adalah konsultasi dengan ahli media dan ahli materi agar mendapatkan saran atau masukan untuk melengkapi dan merevisi draft modul.

3. Menulis Bahan Penilaian

Langkah selanjutnya adalah menulis dan menyusun tes formatif dan yang akan dituangkan ke dalam modul. Tes formatif akan diberikan 10 soal, tipe soal yang diberikan adalah multiple choice. Tes tersebut akan diberikan pada setiap kegiatan pembelajaran untuk mengukur sejauh mana pemahaman peserta pelatihan.

4. Uji Coba dan Memperbaiki Bahan Ajar

Akhirnya, setelah semua tahap telah selesai dilaksanakan, modul akan diujicoba untuk melihat keefetifitasan modul Belajar Berbahasa Mandarin. Tahap ujicoba ini dapat dilakukan dengan beberapa tahapan, seperti Expert Review, One to One, Small Group.

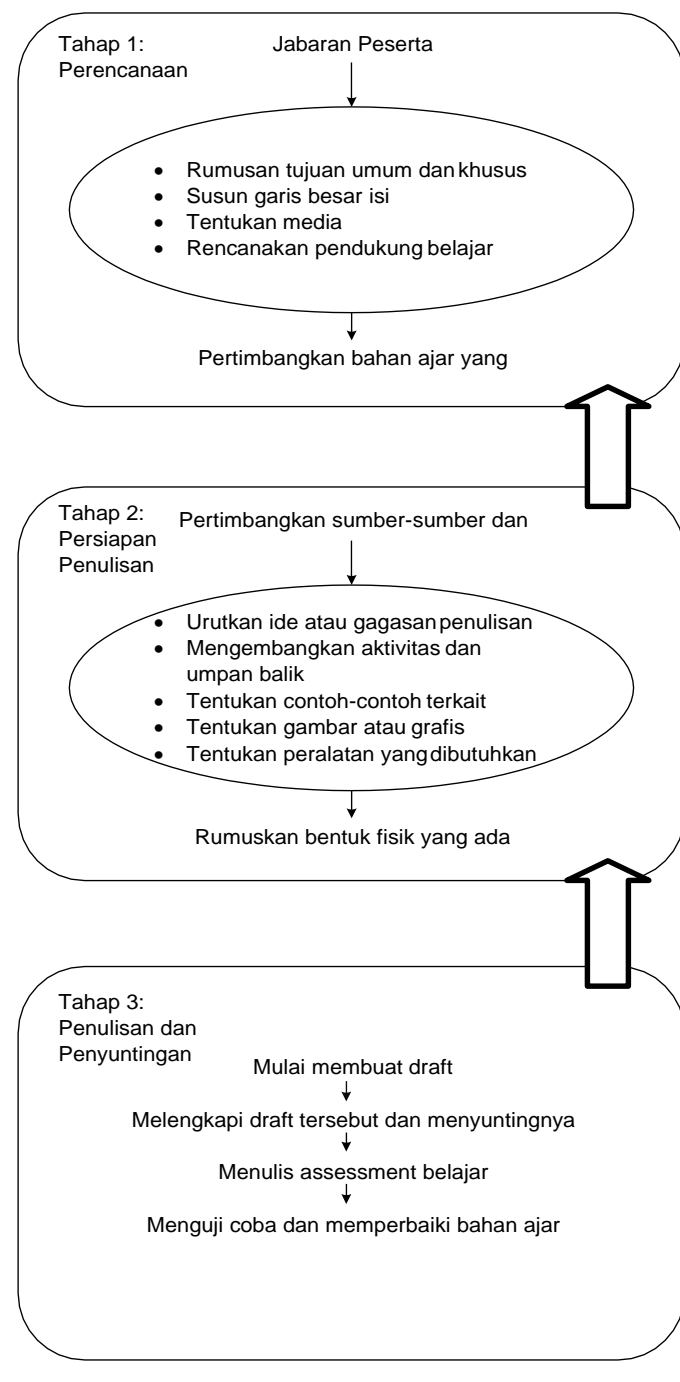

Gambar 1 Model Rowntree

\section{HASIL DAN PEMBAHASAN}

Produk akhir yang dihasilkan dalam pengembangan ini adalah bahan ajar cetak berupa modul. Dalam mengembangkan modul Belajar Berbahasa Mandarin untuk BalaiLatihan Kerja PT.Trias Insan Madani, pengembang mengacu pada model pengembangan produk yang dikemukakan oleh Derek Rowntree. Langkah-langkah model pengembangan Rowntree melalui tiga tahapan pengembangan, yaitu tahap perencanaan, tahap persiapan penulisan, dan tahap penulisan dan penyuntingan. 


\section{Tahap Perencanaan}

1. Profil Peserta Didik,

a) Faktor Demografi,

Peserta Pelatihan semuanya berjenis kelamin perempuan dan usia mereka 23 sampai 28 tahun. Diusia ini mereka dapat dikatakan sebagai orang dewasa. Umumnya orang dewasa secara psikologis memerlukan pengarahan diri dan belajar sesuai dengan kebutuhan yang mereka perlukan. Oleh sebab itu, pengembang menyusun modul ini dengan fokus masalah yang paling banyak dihadapi oleh peserta pelatihan. Materi yang disusun juga berdasarkan kurangnya pemahaman dari peserta pelatihan. Sehingga diharapkan dapat membantu memecahkan masalah yang dihadapi.

b) Faktor Motivasi,

Berdasarkan wawancara dan observasi yang pengembang lakukan, peserta pelatihan memiliki motivasi yang cukup tinggi. Hal ini terlihat karena mereka cukup antusias dalam setiap kegiatan pembelajaran dan mereka langsung bertanya kepada instruktur apabila ada kesulitan dalam proses pembelajaran di kelas maupun di luar kelas. Namun, masih ada beberapa dari mereka yang sering lupa dan sulit mencerna materi yang diberikan.

Atas masalah tersebut dalam mengembangkan modul ini, juga memperhatikan ilustrasi dan contoh-contoh yang diberikan untuk mempermudah peserta pelatihan dalam mengingat materi dan mencerna materi yang diberikan.

c) Faktor Belajar,

Peserta pelatihan mengaku kurang bisa dalam menyusun kalimat berbahasa mandarin, mereka sering terbilik-balik dalam menyusun kalimatnya. Sehingga dalam pelafalannya juga sering terbalik-balik.

Orang dewasa sudah bisa akan belajar mandiri, mereka akan siap belajar apabila materi belajarnya sesuai dengan apa yang mereka perlukan dan memecahkan masalah dalam pekerjaannya. Dalam masalah ini pengembang memberikan contoh-contoh percakapan dan latihan-latihan yang sesuai dengan pekerjaan mereka, sehiingga mereka bisa berlatih secara mandiri ataupun berdiskusi dengan temannya melalui modul yang dikembangkan.

d) Faktor Sumber Belajar,

Dalam proses pembelajaran, peserta pelatihan dan instruktur memanfaatkan modul sederhana yang disusun sendiri. Sumber belajar yang sudah ada tersebut kurang menunjang proses pembelajaran, karena di dalam modul tersebut tidak adanya latihan-latihan soal, materi yang disusun belum terssusun dengan baik, hanya berisi beberapa kata dan kalimat dalam bahasa mandarin, sehingga belum adanya contoh-contoh yang dapat membantu peserta pelatihan dalam mempermudah memahami materinya.

2. Merumuskan Tujuan Pembelajaran

a) Tujuan Pembelajaran Umum

Setelah mempelajari modul ini, diharapkan peserta pelatihan dapat berbicara dalam bahasa Mandarin dalam melakukan pekerjaan mereka sehari-hari.

b) Tujuan Pembelajaran Khusus

- Memperkenalkan diri menggunakan bahasa Mandarin dengan benar

- Mampu menunjukkan waktu dalam bahasa Mandarin

- Menerima telepon dalam bahasa Mandarin

- Mampu melakukan tawar menawar harga dalam bahasa Mandarin

- Menyebutkan nama makanan dan alat dapur dalam bahasa Mandarin

3. Menyusun Garis Besar Isi

\begin{tabular}{|c|c|}
\hline $\begin{array}{c}\text { Pokok } \\
\text { Bahasan }\end{array}$ & Sub-Pokok Bahasan \\
\hline $\begin{array}{l}\text { Perkenalan } \\
\text { Diri }\end{array}$ & $\begin{array}{l}\text { - Cara memperkenalkan diri } \\
\text { - Contoh percakapan tanya } \\
\text { Jawab }\end{array}$ \\
\hline
\end{tabular}




\begin{tabular}{|c|c|}
\hline & $\begin{array}{l}\text { - Kosa kata dalam menyapa } \\
\text { seseorang } \\
\text { - Contoh percakapan } \\
\text { mengenai perkenalan diri }\end{array}$ \\
\hline $\begin{array}{l}\text { Bilangan } \\
\text { dan Waktu }\end{array}$ & $\begin{array}{l}\text { - Kosa kata bilangan } \\
\text { - Kosa kata waktu } \\
\text { - Contoh percakapan }\end{array}$ \\
\hline $\begin{array}{l}\text { Menerima } \\
\text { Telepon }\end{array}$ & $\begin{array}{l}\text { - Kosa kata dalam menerima } \\
\text { telepon } \\
\text { - Contoh percakapan dalam } \\
\text { menerima telepon }\end{array}$ \\
\hline Berbelanja & $\begin{array}{l}\text { - Kosa kata dalam berbelanja } \\
\text { - Contoh percakapan dalam } \\
\text { berbelanja }\end{array}$ \\
\hline $\begin{array}{l}\text { Makanan } \\
\text { dan Alat } \\
\text { Dapur }\end{array}$ & $\begin{array}{l}\text { - Kosa kata macam-macam } \\
\text { makanan } \\
\text { - Kosa kata alat-alat dapur } \\
\text { - Contoh percakapan dalam } \\
\text { menyajikan makanan }\end{array}$ \\
\hline $\begin{array}{l}\text { Rumah } \\
\text { Tangga }\end{array}$ & $\begin{array}{l}\text { - Kosa kata mengenai alat-alat } \\
\text { rumah tangga } \\
\text { - Contoh percakapan } \\
\text { mengenai pekerjaan rumah }\end{array}$ \\
\hline
\end{tabular}

Tabel 1 Garis Besar Isi Materi

\section{Menentukan Media}

Berdasarkan hasil analisis yang dilakukan pada tahap-tahap sebelumnya, yaitu mulai dari profil peserta didik, perumusan tujuan pembelajaran, dan menyusun garis besar isi. Maka dipilihlah modul cetak yang dianggap sesuai untuk dikembangkan dalam menunjang pelatihan bahasa Mandarin di PT.Trias Insan Madani.

\section{Merencanakan Pendukung Belajar Pendukung pembelajaran dalam menggunakan modul ini antara lain :}

a) Instruktur sebagai fasilitator yang akan mengarahkan dan membimbing siswa dalam menggunakan modul ini.

b) Menggunakan modul terdahulu sebagai sumber belajar tambahan apabila materi masih ada yang kurang

6. Mempertimbangkan Bahan Belajar yang Sudah Ada

Balai Latihan Kerja sudah memiliki modul sendiri, namun modul tersebut memiliki beberapa kekurangan, yaitu :

- Belum adanya latihan atau alat evaluasi

- Materi belum tersusun dengan baik

- Belum adanya contoh-contoh atau ilustrasi yang membantu peserta pelatihan memahami materi, hanya berisi kata - kata dan kalimat-kalimat

Selain itu, pengembang juga menganalisis beberapa bahan yang dijadikan referensi, yaitu buku yang terkait dengan pembelajaran bahasa Mandarin dan channel youtube belajar bahasa Mandarin.

\section{Tahap Persiapan Penulisan}

1. Mempertimbangkan sumber daya dan hambatannya

Sumber daya yang digunakan dalam pengembangan ini adalah sumber daya manusia, sumber daya pustaka, dan video pembelajaran.

Sumber daya yang digunakan antara lain:

a) Sumber daya manusia, meliputi Louse Nur Trias dan Louse Nila selaku ketua balai latihan kerja dan instruktur pelatihan bahasa mandarin

b) Sumber daya pustaka, meliputi bukubuku yang berhubungan dengan materi belajar bahasa mandarin, yaitu buku Bahasa Mandarin untuk Pemula dan Percakapan Mandarin Praktis

c) Video pembelajaran, meliputi video berasal dari channel youtube "Chi O Lala"

\section{Mengurutkan Ide}

Tahapan ini pengembang mengurutkan ide dan garis besar isi materi yang telah dibuat sebelumnya dijabarkan lebih luas lagi. 


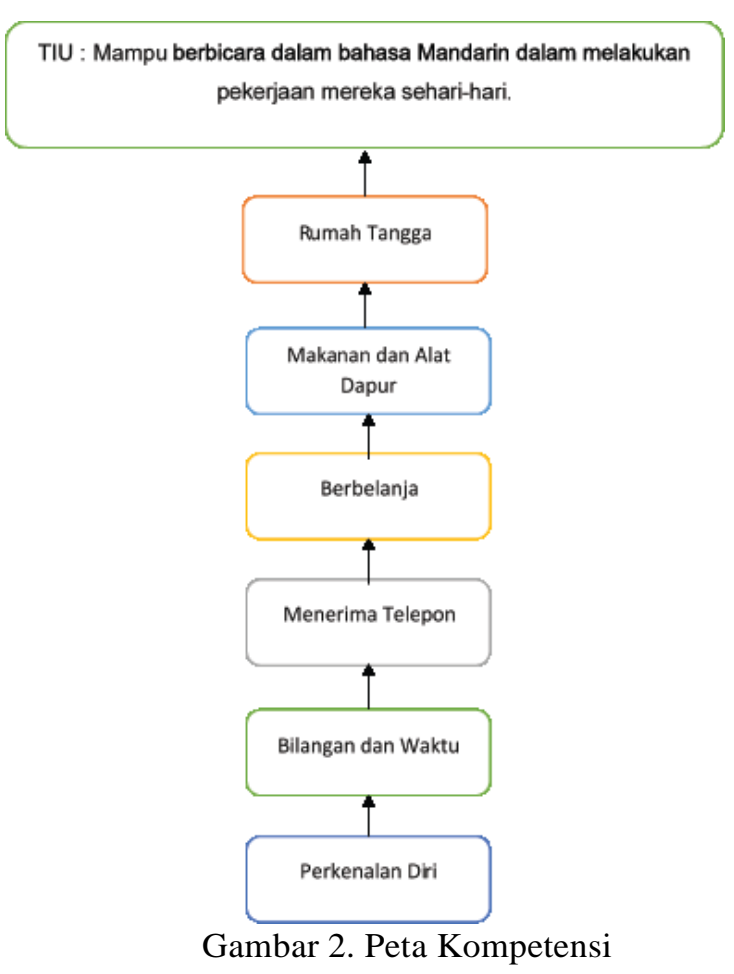

3. Mengembangkan Aktivitas dan Umpan Balik Peserta pelatihan dapat menggunakan modul pada saat pembelajaran dikelas maupun digunakan secara mandiri. Apabila peserta pelatiahan mengalami kesulitan, mereka dapat bertanya kepada instruktur yang bertugas untuk membimbing mereka dalam mencapai tujuan pembelajaran.

Modul yang dikembangkan juga memiliki tes formatif dan umpan balik bagi peserta pelatihan. Apabila mereka telah menyelesaikan satu kegiatan belajar maka mereka dapat mengerjakan soal-soal yang berada pada akhir kegiatan belajar. Instruktur dapat mengukur kemampuan mereka dengan melihat nilai yang diperoleh, apabila kurang dari 80 maka mereka diminta untuk mempelajari lagi materi tersebut sebagai prasyarat untuk lanjut ke materi selanjutnya.

\section{Mengurutkan contoh-contoh Terkait}

Contoh yang diberikan berupa ilustrasi percakapan tentang pekerjaan yang akan mereka lakukan sehari-hari. Contoh-contoh tersebut diambil dari pengalaman instruktur yang telah bekerja disana dan ada juga yang dibuat sendiri kemudian di diskusikan oleh instruktur.

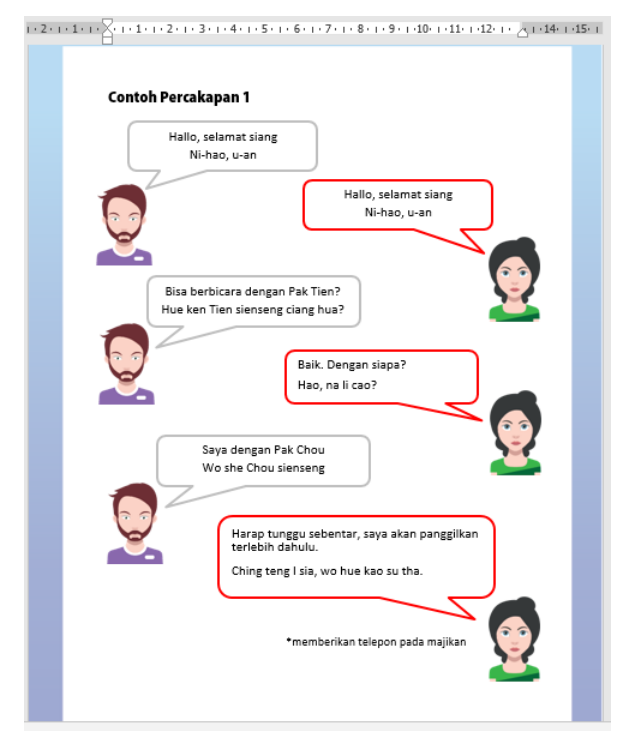

Gambar 3. Contoh Percakapan pada Modul

\section{Menentukan Grafis}

Grafis yang digunakan pada modul ini kebanyakan menggunakan fitur shape yang ada pada Microsoft Word 2016 dan dipadukan dengan icon karakter untuk menghidupkan dialog setiap percakapan

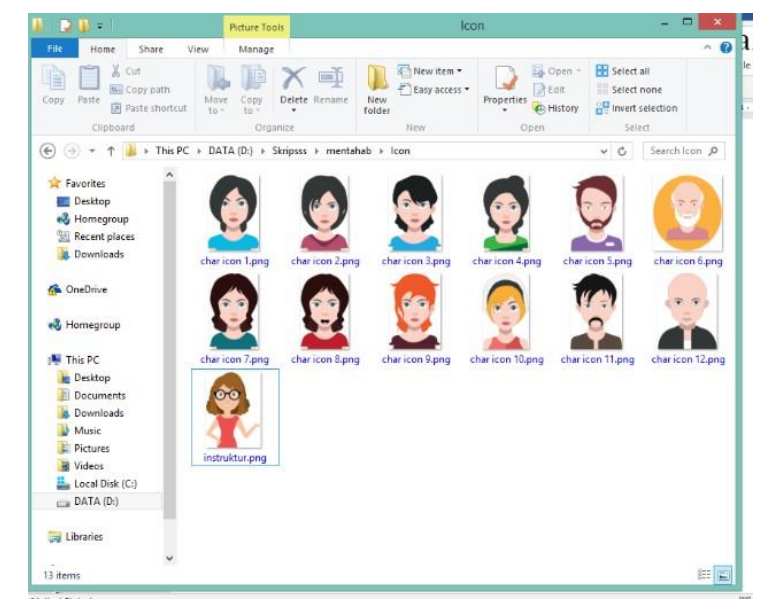

Gambar 4. Contoh Grafis pada Modul

6. Menentukan peralatan yang digunakan Sesuai peralatan yang dimiliki oleh pengembangan, peralatan yang digunakan untuk membuat modul belajar berbahasa mandarin adalah computer dengan processor 
core i3 dan menggunakan system operasi windows 8

7. Merumuskan bentuk fisik modul

a) Pengemasan modul dalam bentuk cetak yang dijilid dengan lem panas

b) Isi buku dicetak pada kertas HVS 100 gram, cover tiap kegiataan belajar dicetak pada kertas ArtPaper 70 gram, cover buku dicetak pada kertas Art Carton 230 gram dengan laminating doft

c) Modul dibuat dengan ukuran kertas b5 $(18,2 \mathrm{~cm} \times 25,7 \mathrm{~cm})$ dan dicetak pada digital printing agar hasil dan warnanya lebih bagus

d) Orientasi modul dengan format portrait agar peserta pelatihan lebih mudah dalam menggunakan modul tersebut

e) Ukuran margin atas $3 \mathrm{~cm}$, bawah $3 \mathrm{~cm}$, kiri $4 \mathrm{~cm}$, kanan $3 \mathrm{~cm}$

f) Ilustrasi diletakkan setiap kegiatan belajar untuk mempermudah pemahaman

g) Jenis huruf yang digunakan adalah Candara untuk isi materi dengan ukuran 12-14pt, sedangkan jenis huruf Myriad Pro digunakan untuk judul dan learning guide dengan ukuran 14-16Pt.

\section{Tahap Penulisan dan Penyuntingan}

1. Memulai membuat draft

Pengembang memulai membuat draft dengan cara membuat tabel berisikan materi kosakata bahasa Mandarin pada Microsoft Excel 2016, kemudian dipindahkan ke Microsoft Word 2016

2. Melengkapi dan menyunting draft pertama Setelah menyusun kosakata bahasa

Mandarin, kemudian pengembang melengkapinya lagi dengan menambahkan learning guide dan kata sapaan pada setiap materi.
3. Menulis Evaluasi Belajar

Evaluasi yang dikembangkan merupakan latihan dan tes formatif yang diberikan pada setiap kegiatan belajar. Setiap kegiatan belajar berisi latihan untuk memotivasi peserta pelatihan dan tes formatif untuk mengukur tingkat pemahaman peserta pelatihan.

4. Mengujicoba dan memperbaiki isi materi modul

Uji coba dilakukan beberapa tahap, yaitu expert review, on-to-one, dan small group. Saat tahap uji coba pengembang mendapatkan masukan dari para ahli. Berikut ini adalah halhal yang disampaikan ketika melakukan expert review dengan para ahli :

a) Review ahli materi oleh Rizky Wardhani, S.S, M.Pd, MTCSOL dan Kepala BLK PT.Trias Insan Madani

Hasil rekapitulasi expert review yang di dapat dari ahli materi adalah 5,72 dari 7. Hal tersebut menunjukkan bahwa modul belajar ini dapat dikatakan sangat baik.

b) Review ahli media oleh Retno

Widyaningrum M.Pd

Hasil rekapitulasi expert review yang di dapat oleh ahli media adalah 6,25 daru 7. Hal tersebut menunjukkan bahwa modul belajar ini dapat dikatakan sangat baik

c) Review ahli desain pembelajaran oleh Dra. Suprayekti, M.Pd

Hasil rekapitulasi expert review yang di dapat oleh ahli desain pembelajaran adalah 5,63 dari 7. Hal tersebut menunjukkan bahwa modul belajar ini dapat dikatakan sangat baik.

\section{SIMPULAN}

Pengembangan ini menghasilkan produk berupa modul cetak yang dikembangkan secara sistematis dengan megacu pada model Rowntree. Modul ini berisikan materi tentang dasar-dasar belajar bahasa Mandarin yang ditujukkan untuk peserta pelatihan atau calon tenaga kerja Indonesia yang akan bekerja di Taiwan. Modul ini dikembangkan karena dilatarbelakangi kurang adanya modul yang memadai di Balai Latihan Kerja PT.Trias Insan Madani. Tujuannya adalah untuk membantu peserta pelatihan dalam berbicara bahasa Mandarin dalam pekerjaan yang akan dilakukan sehari-hari nantinya. 
Pengembangan modul ini, mengacu pada modul Rowntree yang terdiri dari tahap perencanaan, tahap persiapan penulisan, tahap penyuntingan.

\section{UCAPAN TERIMA KASIH}

Segala puji dan syukur penulis panjatkan kepada Allah SWT atas kasih dan rahmat-Nya penulis dapat menyelesaikan jurnal ini. Penulis mengucapkan terima kasih kepada semua staff dan dosen Program Studi Teknologi Pendidikan yang telah banyak berjasa kepada penulis selama berkuliah di UNJ, terima kasih atas ilmunya. Penulis ingin berterima kasih khususnya kepada dosen pembimbing I yaitu Bapak Cecep Kustandi dan dosen pembimbing II yaitu Bapak Kunto Imbar Nursetyo yang telah meluangkan waktu, pikiran dan tenaga serta dengan sabar membimbing dan mengarahkan penulis dalam menyelesaikan skripsi ini. Penulis ucapkan terima kasih kepada pihak Balai Latihan Kerja PT. Trias Insan Madani yang telah memberikan izin dan memfasilitasi untuk melakukan penelitian di tempat tersebut, terutama kepada Kepala Balai Latihan Kerja Ibu Zain Nur Fitriani dan Louse Nila yang senantiasa membantu dan membimbing dalam pengembangan modul ini. Tidak lupa juga ingin berterima kasih kepada Ibu Rizky Wardhani, Ibu Retno Widyaningrum, dan Ibu Dra. Suprayekti untuk memberikan waktunya kepada pengembang melakukan review expert.

\section{DAFTAR PUSTAKA}

Eko Yulianto, Fitri Fatichatul Hidayah. 2016. "Role Playing Perspektif Calon Guru Pendidikan Kimia Universitas Muhammadiyah Semarang", Vol. 4 No.1

Hamiyah, Nur dan Mohammad Jauhar. 2014. Strategi Belajar Mengajar di Kelas. Jakarta. Prestasi Pustakarya

Kent. L. Gustafson dan Robert Maribe Branch. 2002. Survey of Instructional Development Models. Educational Resources Information Center

Miarso, Yusufhadi. 2011. Menyemai Benih Teknologi Pendidikan. Jakarta. Kencana Pranada Media Group

Mustofa, H. Kamil. 2012. Model Pendidikan dan Pelatihan : Konsep dan Aplikasi.Bandung : Alfabeta.
Nurfauzia Heryuliandini dan Robinson Situmorang dan Suprayekti, 2018 "Pengembangan Buku Panduan Mentor di Komunitas Duta Cilik Anti Rokok", Vol. 1 No. 1

Riyana, Cepi dan Rudi Susilana. 2008. Media Pembelajaran. Bandung. CV Wacana Prima

Robert L. Baker dan Richard E. Schutz. 1971. Instructional Product Development. New York. Van Nostrand Reinhold Co

Rowntree, Derek. 1994. Preparing Materials for Open, Distance and Flexible Learning. London. Kogan

Salma, Dewi Prawiradilaga. 2007. Prinsip Desain Pembelajaran. Jakarta. Kencana

Sanjaya, Wina. 2012. Perencanaan dan Desain Sistem Pembelajaran. Jakarta. Kencana Prenada Media Group

Sitepu, B.P. 2006. Penyusunan Buku Pelajaran. Jakarta. Verbum Publishing

Sitepu, B.P. 2006. Penulisan Buku Teks Pelajaran. Jakarta. Rosdakarya

Sukiman. 2012. Pengembangan Media Pembelajaran. Yogyakarta. Pendagogia

Suparman, Atwi. 2010. Desain Instruksional. Jakarta. Universitas Terbuka 